\section{A Poesia Hipermidiática como um Recurso no Processo de Ensino e Aprendizagem da Bioética}

\section{Silva, Paulo Fraga da}

Universidade Presbiteriana Mackenzie, São Paulo, SP, Brasil.E-mail: paulofragadasilva@gmail.com

PALAVRAS-CHAVE: Ensino e Aprendizagem de Bioética, Poesia Hipermidiática, Estratégia didático-pedagógica

O presente trabalho busca apresentar a poesia hipermidiática como um recurso pedagógico no ensino da Bioética. Consideramos que a relação existente entre professor e aluno se faz no cotidiano, e que é neste tempo em andamento, que se desenvolve o processo de ensino e aprendizagem. Evidentemente o foco deve voltar-se à aprendizagem, que precisa ser significativa, pois o aluno necessita relacioná-la ao seu universo de conhecimento, às suas experiências pessoais. Assim, é indispensável, que o aluno participe ativamente de todo o processo cabendo ao professor o papel de facilitador do aprendizado, de criador de condições para que o estudante adquira, vivencie e experimente o conhecer. Sabemos das inúmeras mudanças que passa a educação decorrente das mudanças da sociedade e do mundo em geral, muitas delas em função das transformações das tecnologias da informação e comunicação. Entre estas mudanças uma nova linguagem surgiu: a hipermídia. Seu suporte, que tende a tornar-se mais acessível a cada dia, vem tornando-se menos obscuro e mais compreensivo, principalmente para o estudante. A hipermídia traz em si a possibilidade da tentativa do explorar das linguagens, entre elas a verbal, a imagética e a sonora. Considera-se que o fazer poético é uma ideia em andamento e que o texto artístico rompe barreiras, ou seja, não se prende a fórmulas e, portanto, harmoniza-se com um dos suportes hipermidiáticos, no caso, o computador [1]. A partir da experiência de ensino, através de uma série de Debates em Bioética junto a alunos de um curso de Biologia, foi possível instrumentalizar os alunos nas possibilidades poéticas da informática levando-os à aquisição de novas habilidades, à busca de uma variada gama de informações, até a possibilidade de modificação de atitude e comportamento, uma vez que os mesmos trabalharam conceitos significativos a si, em um contexto realístico, sendo estimulado em um relacionamento interpessoal e invocado a fornecer resultados de sua experiência. Neste sentido, é que a riqueza de tal abordagem metodológica pode propiciar ao ensino da Bioética, uma vez que rompe barreiras de um aprendizado tradicional, explicitando conteúdos atitudinais, permitindo, assim, colocar numa matriz afetiva toda a riqueza do temário bioético [2].

AGRADECIMENTOS. Adriano Palharini, Eduardo Lima, Gabriela Menezes, Giulia Nigro, Lorena Pantaleon e Mariana
Silva - alunos que produziram a poesia hipermidiática "Fome versus Produção de Alimento".

\section{REFERÊNCIAS}

[1] W, Azevedo. Interpoesia e Interprosa: escrituras poéticas digitais. Texto Digital, Florianópolis, Santa Catarina, Brasil, v. 12, n. 1, p. 240-257, (jan./jun. 2016). Disponível em: https://periodicos.ufsc.br/index.php/textodigital/article/view/ 1807-9288.2016v12n1p240

[2] P. F. Silva. Bioética e valores: um estudo sobre a formação de professores de Ciências e Biologia. São Paulo [tese]. (2008). São Paulo: Faculdade de Educação da Universidade de São Paulo. 